\title{
Enhancement of glacial solute fluxes in the proglacial zone of a polythermal glacier
}

\author{
J. L Wadham, ${ }^{1}$ R. J. Cooper, ${ }^{1}$ M. Tranter, ${ }^{1}$ R. Hodgkins ${ }^{2}$ \\ ${ }^{1}$ Bristol Glaciology Centre, School of Geographical Sciences, University of Bristol, Bristol BS8 1SS, England \\ ${ }^{2}$ Department of Geography, Royal Holloway, University of London, Egham, Surrey TW20 0EX, England
}

\begin{abstract}
Annual proglacial solute fluxes and chemical weathering rates at a polythermal high-Arctic glacier are presented. Bulk meltwater chemistry and discharge were monitored continuously at gauging stations located at the eastern and western margins of the glacier terminus and at "the Outlet", $2.5 \mathrm{~km}$ downstream where meltwaters discharge into the fjord. Fluxes of non-snowpack $\mathrm{HCO}_{3}^{-}, \mathrm{SO}_{4}{ }^{2-}, \mathrm{Ca}^{2+}$ and $\mathrm{Mg}^{2+}$ increase by $30-47 \%$ between the glacier terminus and the Outlet, indicating that meltwaters are able to access and chemically weather efflorescent sulphates, carbonates and sulphides in the proglacial zone. Smaller increases in the fluxes of non-snowpack-derived $\mathrm{Na}^{+}, \mathrm{K}^{+}$and $\mathrm{Si}$ indicate that proglacial chemical weathering of silicates is less significant. En3hanced solute fluxes in the proglacial zone are mainly due to the chemical weathering of active-layer sediments. The $P \mathrm{CO}_{2}$ of active-layer ground-waters is above atmospheric pressure. This implies that solute acquisition in the active layer involves no drawdown of $\mathrm{CO}_{2}$. The annual proglacial chemical weathering rate in 1999 is calculated to be $2600 \mathrm{meq} \Sigma^{+} \mathrm{m}^{-2}$. This exceeds the chemical weathering rate for the glaciated part of the catchment $\left(790 \mathrm{meq} \Sigma^{+} \mathrm{m}^{-2}\right)$ by a factor of 3.3. Hence, the proglacial zone at Finsterwalderbreen is identified as an area of high geochemical reactivity and a source of $\mathrm{CO}_{2}$.
\end{abstract}

\section{INTRODUGTION}

Proglacial environments have undergone significant variations in spatial distribution over the Quaternary due to the advance and retreat of glaciers and ice sheets. For example, up to $\sim 28 \%$ of the modern land surface in the Northern Hemisphere may have been in the proglacial zone at some stage during deglaciation (Gibbs and Kump, 1994). There has been considerable focus upon chemical weathering processes in glacierized environments and their potential to draw down $\mathrm{CO}_{2}$ from the atmosphere (Sharp and others, 1995; Hodgkins and others, 1997; Wadham and others, 1997). Chemical weathering rates and mechanisms within the proglacial environment are poorly documented in comparison.

Recent empirical studies have shown that cation weathering rates beneath terrestrial ice are higher than the continental average (Reynolds and Johnson, 1972; Metcalf, 1986; Sharp and others, 1995; Wadham and others, 1997), and are similar to those in temperate environments with similar runoff (Anderson and others, 1997). Subglacial chemical weathering may proceed by reactions that do not consume atmospheric $\mathrm{CO}_{2}$ (Tranter and others, in press), such as carbonate hydrolysis (Equation (1)), sulphide oxidation (Equation (2)) and the oxidation of organic carbon (Equation (3)):

Carbonate hydrolysis

$\mathrm{CaCO}_{3}(\mathrm{~s})+\mathrm{H}_{2} \mathrm{O}(\mathrm{aq}) \leftrightarrow \mathrm{Ca}^{2+}(\mathrm{aq})+\mathrm{HCO}_{3}^{-}(\mathrm{aq})+\mathrm{OH}^{-}(\mathrm{aq})$
calcite

Coupled pyrite oxidation/carbonate dissolution

$4 \mathrm{FeS}_{2}(\mathrm{aq})+16 \mathrm{CaCO}_{3}(\mathrm{~s})+15 \mathrm{O}_{2}(\mathrm{~g})+14 \mathrm{H}_{2} \mathrm{O}(\mathrm{l})$ pyrite
$16 \mathrm{Ca}^{2+}(\mathrm{aq})+16 \mathrm{HCO}_{3}{ }^{-}(\mathrm{aq})+8 \mathrm{SO}_{4}{ }^{2-}(\mathrm{aq})+4 \mathrm{Fe}(\mathrm{OH})_{3}(\mathrm{~s})$

ferric oxyhydroxide

Oxidation of organic carbon

$$
\mathrm{C}_{\mathrm{org}}(\mathrm{s})+\mathrm{O}_{2}(\mathrm{~g}) \leftrightarrow \mathrm{CO}_{2}(\mathrm{~g})
$$

The proglacial zone is potentially highly geochemically reactive (Gibbs and Kump, 1994), since it contains comminuted subglacial material in chemical weathering environments where rock/water ratios and contact times are high and there is an abundant water supply from glacierized environments. However, few studies exist that confirm this. No study has quantified total solute fluxes from, and the rate of chemical weathering within, the proglacial zone of a glacier over an entire melt season.

Whether or not the proglacial zone represents a source or sink of $\mathrm{CO}_{2}$ is unknown. Soil development is virtually nonexistent in terrain that has been deglaciated over time-scales of $<100$ years. Thus, unless proglacial sediments contain fossil soils, produced during earlier warm periods, that were subsequently overridden by ice, root respiration and the oxidation of recent organic matter are unlikely to be major sources of $\mathrm{CO}_{2}$ for chemical weathering of the regolith. This contrasts with temperate environments (Holland, 1978). Proglacial chemical weathering might therefore be driven by the direct drawdown of atmospheric $\mathrm{CO}_{2}$ (Equations (4) and (5)) 
Acid hydrolysis (carbonation) of carbonates (1) and silicates (2) $\mathrm{CaCO}_{3}(\mathrm{~s})+\mathrm{H}_{2} \mathrm{O}(\mathrm{l})+\mathrm{CO}_{2}(\mathrm{aq}) \leftrightarrow \mathrm{Ca}^{2+}(\mathrm{aq})+2 \mathrm{HCO}_{3}^{-}$(aq) calcite

$$
\begin{aligned}
& \mathrm{CaAl}_{2} \mathrm{Si}_{2} \mathrm{O}_{8}(\mathrm{~s})+2 \mathrm{CO}_{2}(\mathrm{aq})+2 \mathrm{H}_{2} \mathrm{O}(\mathrm{l}) \\
& \text { anorthite } \leftrightarrow \\
& \mathrm{Ca}^{2+}(\mathrm{aq})+2 \mathrm{HCO}_{3}{ }^{-}(\mathrm{aq})+\mathrm{H}_{2} \mathrm{Al}_{2} \mathrm{Si}_{2} \mathrm{O}_{8}(\mathrm{~s}) \\
& \text { weathered feldspar surface }
\end{aligned}
$$

or alternative mechanisms, such as carbonate hydrolysis (Equation (1)), sulphide oxidation (Equation (2)) and the microbial oxidation of kerogen in rocks (Equation (3)). Anderson and others (2000) show that coupled carbonate dissolution/sulphide oxidation (Equation (2)) dominates solute acquisition in young proglacial sediments, and that silicate dissolution increases in significance as reactive minerals such as carbonates and sulphides become exhausted.

This paper documents solute fluxes and chemical weathering rates in the proglacial zone of Finsterwalderbreen, Svalbard, a polythermal high-Arctic glacier. The hydrochemistry of bulk meltwaters sampled from three monitoring stations located at either end of a $2.5 \mathrm{~km}$ proglacial reach is compared. The data are used to calculate solute fluxes and chemical weathering rates in the proglacial zone relative to those in the upstream glacial environment, and to infer where and by what means solute is acquired in the proglacial zone.

\section{STUDY AREA}

Finsterwalderbreen $\left(77^{\circ} 28^{\prime} \mathrm{N}, 15^{\circ} 18^{\prime} \mathrm{E}\right)$ is a high-Arctic glacier, located on the south side of Van Keulenfjorden, south Svalbard (Fig. la). A full description of the field site can be found in Wadham and others (1998). The $44 \mathrm{~km}^{2}$ glacier has a polythermal regime. It is mainly warm-based, except for the terminal 500-700 $\mathrm{m}$ and the edges (Ødegård and others, 1997). It possesses a subglacial hydrological system (Wadham and others, 1998). The proglacial plain is characterized by an outer zone of push moraines resulting from surges (Hart and Watts, 1997), the last inferred to have occurred between 1898 and 1911 (Liestøl, 1969; Nuttall and others, 1997). Adjacent to the glacier is an inner zone of chaotic topography, including smaller push moraines and widespread fluvial deposits (Hart and Watts, 1997). Most moraines were deposited during the last 100 years. The areal extent of the proglacial zone is $\sim 4.2 \mathrm{~km}^{2}$, most of which has become exposed by glacier retreat at a rate of $10-40 \mathrm{~m} \mathrm{a}^{-1}$ since the termination of the last surge (Nuttall, 2000). The moraine and the fluvioglacial sediments in the proglacial zone contain material from all elements of the catchment lithology (Precambrian carbonates, phyllite and quartzite, Permian sandstones, dolomites and limestones and Triassic to Cretaceous siltstones, sandstones and shales (Dallmann and others, 1990)). There is no gypsum in the catchment lithology.

The western glacier margin is drained by two outflows, a subglacial upwelling and an ice-marginal channel (Fig. lb). Together, these contribute $\sim 70 \%$ of the glacial runoff. These meltwaters initially flow for $\sim 1.25 \mathrm{~km}$ parallel to the terminus in a confined channel, of which $\sim 0.5 \mathrm{~km}$ is incised into fields of naled ice. Beyond the channel, the stream collapses into an unconfined network of braided channels. An ice-marginal channel drains the eastern margin. These meltwaters are added to the braided-stream network and form the remaining $\sim 30 \%$ of bulk runoff. The braided stream conveys meltwaters for $\sim 0.75 \mathrm{~km}$, before re-forming a single channel and discharging into the fjord a further

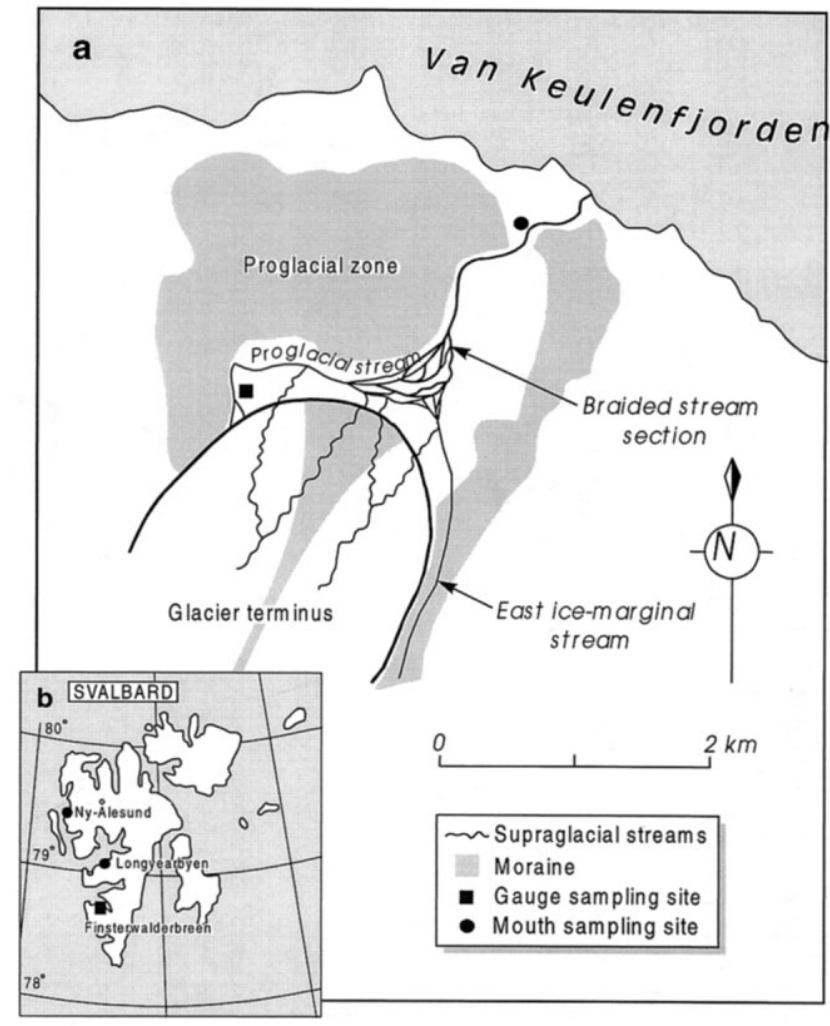

Fig. 1. (a) Sketch map of the proglacial zone. (b) Location map of Finsterwalderbreen.

$\sim 0.5 \mathrm{~km}$ downstream. There are a number of direct water inputs to the proglacial bulk meltwaters during their course. A complex network of lakes, linked by small streams, exists throughout the proglacial moraine system. The streams drain the active layer, conveying meltwaters along a topographic gradient from the interior of the moraine system to the proglacial flood plain and channel. Some meltwater follows diffuse subsurface flow paths. Several minor supraglacial streams also flow directly from the glacier terminus into the proglacial zone. The mean combined discharge of these supraglacial streams was estimated by manual gauging to be $<1 \mathrm{~m}^{3} \mathrm{~s}^{-1}(<2 \%$ total discharge).

\section{METHODS}

\section{Field methods}

The meltwater sampling reported here was conducted from 24 June to 16 August during the 1999 ablation season.

Three gauging stations were established at the start of the sampling season. They were located on both sides of the glacier terminus in order to monitor glacial water and solute fluxes. The West gauging station was positioned $\sim 150 \mathrm{~m}$ downstream from the confluence of the west ice-marginal channel with the upwelling (see Fig. 1b). The East gauging station was located at the margin of the east ice-marginal channel, $\sim 200 \mathrm{~m}$ from where meltwaters are discharged into the proglacial zone (see Fig. 1b). A single gauging station was established $\sim 2.5 \mathrm{~km}$ downstream from these two sites, with the aim of monitoring water and solute fluxes from the proglacial zone. This site, "the Outlet gauging station", was located at the point where the bulk meltwater stream breaches the outer moraine complex (see Fig. 1b), 100 m from where meltwaters enter the fjord. Bulk meltwaters flowed in welldefined channels at all three gauging stations. The errors in the discharge data are estimated to be $\sim 10-14 \%$. 
Stage was measured at 20 s intervals at the West, East and Outlet gauging stations using Druck pressure transducers. Values were averaged and recorded by Campbell Scientific CR10X dataloggers at hourly intervals. Stage was calibrated every 1-3 days by manual gauging, in which the crosssectional area, depth-averaged velocity and stream width were used to determine discharge. High flows led to the destruction of the West and East gauging stations several times during the sampling season. Missing discharge values for these periods have been estimated from the Outlet discharge record, which was almost continuous throughout the sampling season. Electrical conductivity was also monitored continuously at all three sites using Campbell Scientific temperature/conductivity sensors. Hourly averages of $20 \mathrm{~s}$ values were recorded on Campbell Scientific CR10X dataloggers. Total dissolved solids (TDS), defined as the sum of measured ionic species, were determined from the electrical conductivity records (see Wadham and others, 1998).

Meltwater samples were collected daily at the West and Outlet gauging stations. Sampling at the Outlet gauging station took place $\sim 30$ min after sampling at the West gauging station in order to track the same water parcel as it passed through the proglacial zone. Bulk meltwaters were sampled from the East gauging station only every fourth day due to difficulties of access.

Six wells were sunk in the proglacial active layer along a transect extending perpendicular to a branch of the main bulk meltwater channel at the start of the braided-stream section (see Fig. 1b). The depths of the wells ranged from 0.2 to $0.5 \mathrm{~m}$ below the surface of the active layer. The wells were located 5, 24, 53, 83, 118 and $148 \mathrm{~m}$ from the bulk meltwater channel. Wells situated 5, 24 and $53 \mathrm{~m}$ from the channel were sunk in fine fluvial sediments comprising sand and silt on the channel flood plain. The other three wells were sunk in moraines, situated in more distal locations with respect to the bulk meltwater stream. The height of water in the wells relative to the river channel ranged from $0.7 \mathrm{~m}$ in the nearchannel wells to $1.2 \mathrm{~m}$ in more distal wells. The depth of thaw of the active layer close to the channel increased from a mean of $0.40 \mathrm{~m}$ at the start of the sampling season to $0.75 \mathrm{~m}$ in midAugust. The temperature of ground-waters was monitored every 20 s using combined Campbell Scientific temperature/ conductivity probes inserted in the well. Hourly averages of readings were recorded by a Campbell Scientific CR10X datalogger. A water sample was taken from each of the wells once every 4 days. Wells were purged of water using a plastic syringe prior to sampling. Water samples were drawn from the wells using the syringe, once recharge had taken place. Recharge took 10-30 min.

\section{Sample treatment and laboratory techniques}

All meltwater samples were filtered immediately after collection using $0.45 \mu \mathrm{m}$ cellulose nitrate membrane filters, a hand-held vacuum pump and Nalgene filter units. They were then sealed in clean, low-density polyethylene bottles and stored for 4-6 months prior to analysis for the major cations, anions and dissolved Si. $\mathrm{pH}$ was determined in the field within several days of collection, using an Orion $290 \mathrm{pH}$ meter and a Ross Best Performance $\mathrm{pH}$ electrode and low-ionic-strength buffers of $\mathrm{pH} 4.01,6.97$ and 9.10. The $\mathrm{pH}$ of the samples was not significantly affected by storage, since air was largely excluded from the bottles.

Alkalinity (predominantly $\mathrm{HCO}_{3}{ }^{-}$) was determined by colorimetric titration using $\mathrm{BDH} \mathrm{pH} 4.5$ indicator. The remaining major cations and anions were determined by ion chromatography on a Dionex 4000i Ion Chromatograph. The precision of alkalinity analyses was $\pm 0.1 \%$ at $\mathrm{HCO}_{3}{ }^{-}$ concentrations of $1 \mathrm{mM}$. Lower precision is anticipated at lower concentrations. For example, precision of $50 \%$ is reported elsewhere for low-concentration alkalinity determinations (Tranter and others, 1997). The precision of $\mathrm{SO}_{4}{ }^{2-}$, $\mathrm{Cl}^{-}, \mathrm{Ca}^{2+}, \mathrm{Mg}^{2+}, \mathrm{Na}^{+}$and $\mathrm{K}^{+}$analyses was $\pm 0.9 \%, 7 \%$, $0.6 \%, 0.2 \%, 0.7 \%$ and $20 \%$, respectively. Dissolved $\mathrm{Si}$ concentrations were determined by flow-injection analysis using the molybdenum blue method on a Tecator FIAstar 5010 Flow Injection Analyser, connected to a FIAstar 5023 Spectrophotometer. The precision of analyses was $\pm 8 \%$. Mean charge balance errors (CBEs) (Equation (6)) calculated for samples collected from the West, East and Outlet gauging stations and the wells were $+2.1 \pm 1.7 \%,+2.3 \pm 1.1 \%$, $+2.1 \pm 1.8 \%$ and $0.5 \pm 3.4 \%$, respectively. CBE is defined as

$$
\mathrm{CBE}=\frac{\Sigma^{+}-\Sigma^{-}}{\Sigma^{+}+\Sigma^{-}} \times 100 \%
$$

where $\Sigma^{-}$and $\Sigma^{+}$are the summed equivalents of anions and cations, respectively.

Laboratory dissolution experiments were performed to assess the reactivity of bulk meltwater suspended sediment (SS). SS was obtained from the residues on daily bulk meltwater filter membranes. The filter membranes were not dried prior to storage, and chemical weathering of the wet sediment could have continued for some time after collection, potentially providing readily soluble material on the debris surfaces. Two experiments were conducted under similar conditions using SS concentrations (SSC) of 2 and $3 \mathrm{~g} \mathrm{~L}^{-1}$. In the first experiment $\left(\mathrm{SSC}=2 \mathrm{~g} \mathrm{~L}^{-1}\right)$, the sediment was prewashed with deionized water to minimize storage artefacts. In the second experiment $\left(\mathrm{SSC}=3 \mathrm{~g} \mathrm{~L}^{-1}\right.$ ), sediment was not pre-washed. It was added to $1 \mathrm{~L}$ of deionized water held in an open plastic vessel at $0^{\circ} \mathrm{C}$. It was held in suspension by magnetic stirring and the temperature was maintained between $0^{\circ}$ and $4^{\circ} \mathrm{C}$ by housing the apparatus in a refrigerator during the course of the experiment. Aliquots of $10 \mathrm{~mL}$ were removed from the vessel at regular intervals using a plastic syringe and immediately filtered through $0.45 \mu \mathrm{m}$ cellulose nitrate filter membranes into clean polyethelene bottles. This slightly increased the SSC of the remaining solution. The $\mathrm{pH}$ of samples was determined immediately after filtration. The alkalinity of samples was determined a few days after filtration, and $\mathrm{Ca}^{2+}, \mathrm{Mg}^{2+}$ and $\mathrm{SO}_{4}{ }^{2-}$ were determined 1-2 months later, using the same methodology as above.

\section{DATA ANALYSIS}

Concentrations of individual solutes in bulk meltwater samples have been partitioned into their snowpack- and non-snowpack-derived components. The snowpack-derived component is calculated using the mean ionic ratio of $\mathrm{Cl}^{-}$to solute species, $\mathrm{X}$, in fresh snow samples collected in spring 2000 and the $\mathrm{Cl}^{-}$concentration (assumed to be derived entirely from sea salt in the snowpack (Wadham and others, 1998)). Non-snowpack-derived solute is hereafter denoted with an asterisk.

The partial pressure of $\mathrm{CO}_{2}\left(\mathrm{PCO}_{2}\right)$ of bulk meltwaters 


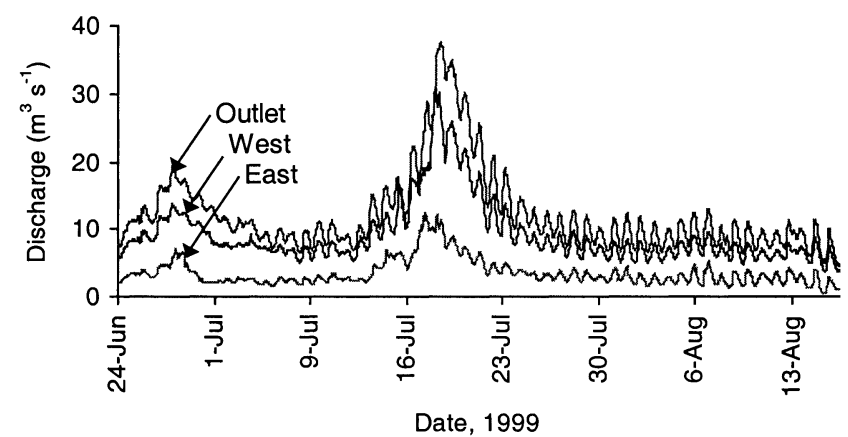

Fig. 2. Temporal variation in bulk runoff at the East, West and Outlet gauging stations during the 1999 sampling season.

sampled at the East, West and Outlet gauging stations has also been calculated:

$$
\mathrm{PCO}_{2}=\frac{\left(\mathrm{HCO}_{3}^{-}\right)\left(\mathrm{H}^{+}\right)}{K_{1} K_{\mathrm{H}}},
$$

where $\left(\mathrm{HCO}_{3}{ }^{-}\right)$and $\left(\mathrm{H}^{+}\right)$are the concentrations of $\mathrm{HCO}_{3}{ }^{-}$ and $\mathrm{H}^{+}$, respectively. $K_{1}$ and $K_{\mathrm{H}}$ are $10^{-6.58} \mathrm{~mol} \mathrm{~L}^{-1}$ and $10^{-1.11}$ mol L ${ }^{-1}$, respectively, at $0^{\circ} \mathrm{C}$ (Plummer and Busenberg, 1982).

The saturation of ground-waters with respect to calcite $\left(\mathrm{SI}_{\mathrm{C}}\right.$, Equation (8)) and gypsum $\left(\mathrm{SI}_{\mathrm{Gyp}}\right.$, Equation (9)) has been calculated using PHREEQGI (Parkhurst and Appelo, 1999). Ion activities and ion pairs are taken into account in these calculations:

$$
\begin{gathered}
\mathrm{SI}_{\mathrm{C}}=\log _{10}\left[\frac{\left(\mathrm{Ca}^{2+}\right)\left(\mathrm{HCO}_{3}^{-}\right)\left(K_{2}\right)}{\left(\mathrm{H}^{+}\right)\left(K_{\mathrm{C}}\right)}\right] \\
\mathrm{SI}_{\mathrm{Gyp}}=\log _{10}\left[\frac{\left(\mathrm{Ca}^{2+}\right)\left(\mathrm{SO}_{4}^{2-}\right)}{K_{\mathrm{G}}}\right],
\end{gathered}
$$

where $K_{\mathrm{C}}, K_{\mathrm{G}}$ and $K_{2}$ are the solubility products of calcite and gypsum and the equilibrium constant for the dissociation of $\mathrm{HCO}_{3}{ }^{-}$, respectively. Calculations were performed using the temperature recorded at the time of sampling.

\section{RESULTS}

\section{Discharge and solute concentration time series}

The temporal variation in bulk runoff measured at the West, East and Outlet gauging stations is displayed in Figure 2. Temporal variation in the concentrations of the major ions, $\mathrm{HCO}_{3}{ }^{-},{ }^{*} \mathrm{SO}_{4}{ }^{2-}$ and $* \mathrm{Ca}^{2+}$, is presented in Figure 3. Concentrations of all three are higher at the Outlet than at the East and West gauging stations. The temporal variation in the $\mathrm{PCO}_{2}$ (Equation (7)) of bulk meltwaters sampled at the East, West and Outlet gauging stations is also presented in Figure 3. The $\mathrm{PCO}_{2}$ of bulk meltwaters at all three sites is greater than atmospheric $P \mathrm{CO}_{2}$ throughout much of the sampling season.

Marked differences are also apparent between East and

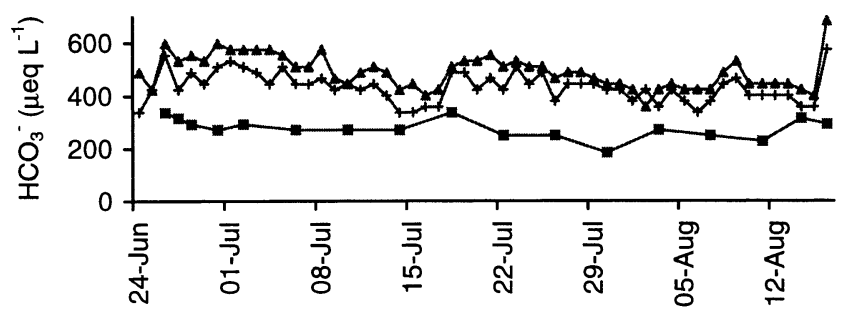

Date, 1999
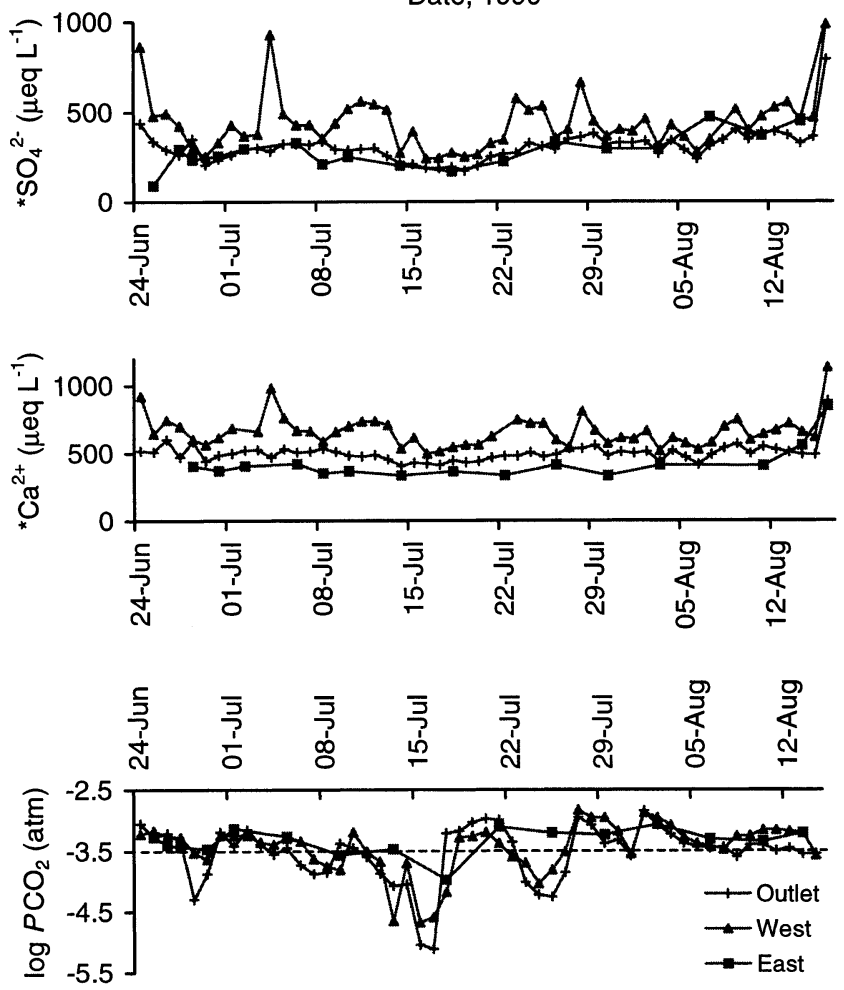

Fig. 3. Temporal variation in the concentrations of $\mathrm{HCO}_{3}{ }^{-}$, $\mathrm{SO}_{4}{ }^{2-}$ and $\mathrm{Ca}^{2+}$ in bulk meltwaters and the $\mathrm{PCO}_{2}$ of bulk meltwaters (atmospheric $\mathrm{PCO}_{2}$ is denoted with a dashed line) sampled at the East, West and Outlet gauging stations during the 1999 sampling season.

West stream hydrochemistry. Both East and West streams capture runoff from ice-marginal and supraglacial environments, but the West stream also includes runoff derived from a concentrated subglacial upwelling (Wadham and others, 1998).

\section{Ground-water hydrochemistry}

The proglacial active layer delivers highly mineralized ground-waters to the main glacial bulk meltwater stream by surface and subsurface flow paths. Table 1 summarizes the chemical composition of ground-waters sampled from fluvial and moraine active-layer sediments during the sampling season. Active-layer ground-waters are highly mineralized and have a $\mathrm{SO}_{4}{ }^{2-}-\mathrm{Ca}^{2+}-\mathrm{Mg}^{2+}-\mathrm{HCO}_{3}{ }^{-}$composition. Virtually

\begin{tabular}{|c|c|c|c|c|c|c|c|c|c|}
\hline & Si & $C l$ & $\mathrm{HCO}_{3}^{-}$ & $\mathrm{SO}_{4}{ }^{2-}$ & $\mathrm{Na}^{+}$ & $K^{+}$ & $\mathrm{Mg}^{2+}$ & $\mathrm{Ca}^{2+}$ & $C B E$ \\
\hline Mean & 17 & 200 & 1700 & 7500 & 220 & 76 & 3200 & 6000 & 0.5 \\
\hline Min. & 8.1 & 55 & 1300 & 2500 & 24 & 30 & 1200 & 2600 & -9.9 \\
\hline Max. & 29 & 510 & 2050 & 19000 & 380 & 320 & 6700 & 13000 & 11 \\
\hline SD & 7.4 & 99 & 190 & 3600 & 91 & 52 & 1300 & 2200 & 3.4 \\
\hline$n$ & 60 & 60 & 60 & 60 & 60 & 60 & 60 & 60 & 60 \\
\hline
\end{tabular}
all ground-waters had a high $\mathrm{PCO}_{2}$ (i.e. atmospheric $P \mathrm{CO}_{2}$

Table 1. Statistical summary of the composition of ground-waters in the active layer (units are $\mu e q L^{-1}$ ) 
Table 2. Statistical summary of the $\mathrm{pH}, \mathrm{PCO}_{2}, \mathrm{SI}_{\mathrm{C}}$ and $\mathrm{SI}_{\mathrm{Gyp}}$ of ground-waters in the active layer

\begin{tabular}{lcccc}
\hline & $p H$ & $P C O_{2}$ & $S I_{\mathrm{C}}$ & $S I_{\text {Gyp }}$ \\
\hline Mean & 8.0 & -3.2 & 0.2 & -1.0 \\
Min. & 7.7 & -3.5 & -0.36 & -1.53 \\
Max. & 8.3 & -2.8 & 0.49 & -0.29 \\
SD & 0.1 & 0.1 & 0.1 & 0.27 \\
$n$ & 60 & 60 & 60 & 60 \\
\hline
\end{tabular}

of $>10^{-3.5} \mathrm{~atm}$ ) and were over-saturated with respect to calcite and under-saturated with respect to gypsum (see Table 2).

\section{Water and solute fluxes}

The water flux from the glacier $\left(Q_{\mathrm{GL}}\right)$ during the sampling season was calculated as,

$$
Q_{\mathrm{GL}}=Q_{\mathrm{W}}+Q_{\mathrm{E}}+Q_{\mathrm{SUPRA}},
$$

where $Q_{\mathrm{W}}$ and $Q_{\mathrm{E}}$ are the total water fluxes measured at the West and East gauging stations, respectively, during the sampling season and $Q_{\text {SUPRA }}$ is the total water flux of the supraglacial streams that drain directly off the glacier terminus. $Q_{\mathrm{W}}$ and $Q_{\mathrm{E}}$ were determined by summing cumulative daily water fluxes at the West and East gauging stations. $Q_{\text {SUPRA }}$ was calculated in a similar manner using a mean daily discharge of $0.8 \mathrm{~m}^{3} \mathrm{~s}^{-1}$.

The proglacial water flux $\left(Q_{\mathrm{PG}}\right)$ during the sampling season is calculated from the measured discharges at the glacier terminus $\left(Q_{\mathrm{GL}}\right)$ and the Outlet gauging station $\left(Q_{\mathrm{O}}\right)$,

$$
Q_{\mathrm{PG}}=Q_{\mathrm{O}}-Q_{\mathrm{GL}} \text {. }
$$

$Q_{\mathrm{O}}$ is determined in a similar manner to $Q_{\mathrm{W}}$ and $Q_{\mathrm{E}} \cdot Q_{\mathrm{GL}}$ and $Q_{\mathrm{PG}}$ are presented in Table 3. The total water flux decreased by $13 \%$ in the proglacial zone. This is within the error of the discharge measurements and does not necessarily indicate that the proglacial zone is a sink for meltwaters. However, some ponding of bulk meltwaters in the proglacial zone was observed during periods of high runoff.

The total flux of the major cations, anions and dissolved
Si from the glacier is equal to the summed fluxes of solute at the East and West gauging stations,

$$
Q_{\mathrm{GL}} C_{\mathrm{GL}}^{\mathrm{i}}=Q_{\mathrm{W}} C_{\mathrm{W}}^{\mathrm{i}}+Q_{\mathrm{E}} C_{\mathrm{E}}^{\mathrm{i}} .
$$

$Q_{\mathrm{GL}} C_{\mathrm{GL}}^{\mathrm{i}}, Q_{\mathrm{W}} C_{\mathrm{W}}^{\mathrm{i}}$ and $Q_{\mathrm{E}} C_{\mathrm{E}}^{\mathrm{i}}$ are the fluxes of solute species "i" from the glacier, East and West gauging stations, respectively, during the sampling season. Solute fluxes in the supraglacial streams draining directly from the terminus are not included since solute concentrations in these streams are minimal (Wadham and others, 1998).

The proglacial solute flux $\left(Q_{\mathrm{PG}} C_{\mathrm{PG}}^{\mathrm{i}}\right)$ can then be calculated by subtracting $Q_{\mathrm{GL}} C_{\mathrm{GL}}^{\mathrm{i}}$ from the solute flux at the Outlet gauging station $\left(Q_{\mathrm{O}} C_{\mathrm{O}}^{\mathrm{i}}\right)$ during the sampling season. $Q_{\mathrm{O}} C_{\mathrm{O}}^{\mathrm{i}}$ is equal to the total solute flux from the Finsterwalderbreen catchment during the sampling season.

$Q_{\mathrm{W}} C_{\mathrm{W}}^{\mathrm{i}}$ and $Q_{\mathrm{O}} C_{\mathrm{O}}^{\mathrm{i}}$ are calculated by multiplying daily bulk meltwater solute concentrations by cumulative daily water fluxes at the West and Outlet gauging stations, respectively. This gives daily solute fluxes, which are then summed to give $Q_{\mathrm{W}} C_{\mathrm{W}}^{\mathrm{i}}$ and $Q_{\mathrm{O}} C_{\mathrm{O}}^{\mathrm{i}}$. These calculations assume that bulk meltwater solute concentrations determined once daily approximate the daily average solute concentration. Analysis of the hourly TDS record for the West and Outlet gauging stations shows that bulk meltwater TDS at the time of bulk water sample collection differs from daily mean TDS by $<10 \%$ and usually by $<5 \%$. This assumption is therefore unlikely to significantly affect the solute flux calculations.

$Q_{\mathrm{E}} C_{\mathrm{E}}^{\mathrm{i}}$ is calculated in a similar manner to $Q_{\mathrm{W}} C_{\mathrm{W}}^{\mathrm{i}}$ and $Q_{\mathrm{O}} C_{\mathrm{O}}^{\mathrm{i}}$. However, since samples were collected from the East gauging station only every 4 days, mean daily solute concentrations for the intervening days have been interpolated using the continuous TDS record at this site.

Daily fluxes of $\mathrm{HCO}_{3}{ }^{-}, \mathrm{SO}_{4}{ }^{2-}$ and $\mathrm{Ca}^{2+}$ at the West, East and Outlet gauging stations are presented in Figure 4. Trends in these fluxes approximately follow those in discharge. Total glacial and proglacial fluxes of $\mathrm{Cl}^{-}, \mathrm{HCO}_{3}{ }^{-}$, $\mathrm{SO}_{4}{ }^{2-}, \mathrm{Ca}^{2+}, \mathrm{Mg}^{2+}, \mathrm{Na}^{+}, \mathrm{K}^{+}$and $\mathrm{Si}$ are presented in Table 3. The non-snowpack and snowpack components of these proglacial and glacial solute fluxes are also presented. The potential proglacial solute flux from naled ice is calculated.

\begin{tabular}{|c|c|c|c|c|c|c|c|c|}
\hline \multirow[t]{3}{*}{ Quantity } & \multirow[t]{3}{*}{ Naled fluxes } & \multicolumn{3}{|c|}{ Glacial solute fluxes ( $\left.Q_{\mathrm{GL}} C_{\mathrm{GL}}^{\mathrm{i}}\right)$} & \multicolumn{3}{|c|}{ Proglacial solute fluxes $\left(Q_{\mathrm{PG}} C_{\mathrm{PG}}^{\mathrm{i}}\right)$} & \multirow{3}{*}{$\begin{array}{c}\left(Q_{\mathrm{PG}} C^{* \mathrm{i}}{ }_{\mathrm{PG}} /\right. \\
\left.Q_{\mathrm{GL}} C_{\mathrm{GL}}^{\mathrm{i}}\right) \times 100\end{array}$} \\
\hline & & Total & Snowpack & Non-snowpack & Total & Snowpack & Non-snowpack & \\
\hline & & $\mathrm{kg}$ & $\mathrm{kg}$ & $\mathrm{kg}$ & $\mathrm{kg}$ & $\mathrm{kg}$ & $\mathrm{kg}$ & \\
\hline $\mathrm{Cl}^{-}$ & 920 & 110000 & 110000 & - & 5200 & 5200 & 0 & 0.0 \\
\hline $\mathrm{HCO}_{3}{ }^{-}$ & 3400 & 1200000 & 2700 & 100000 & 310000 & 140 & 310000 & 26 \\
\hline $\mathrm{SO}_{4}{ }^{2-}$ & 1800 & 680000 & 27000 & 650000 & 250000 & 1400 & 250000 & 47 \\
\hline $\mathrm{K}^{+}$ & 100 & 29000 & 1400 & 28000 & 2800 & 70 & 2800 & 10 \\
\hline $\mathrm{Mg}^{2+}$ & 380 & 120000 & 7200 & 110000 & 35000 & 120 & 35000 & 29 \\
\hline $\mathrm{Ca}^{2+}$ & 1000 & 470000 & 25000 & 450000 & 160000 & 120 & 160000 & 34 \\
\hline $\mathrm{Si}$ & 30 & 14000 & 400 & 14000 & -800 & 0 & 0 & 0.0 \\
\hline \multirow[t]{3}{*}{ Total solutes } & 8700 & 2700000 & 200000 & 2700000 & 770000 & 9900 & 760000 & 29 \\
\hline & Naled & \multicolumn{3}{|c|}{ Glacial water fluxes } & \multicolumn{3}{|c|}{ Proglacial water fluxes } & $\left(\right.$ QFLUX $_{\mathrm{PG}} /$ \\
\hline & $\mathrm{m}^{3}$ & $\mathrm{~m}^{3}$ & $\mathrm{~m}^{3}$ & $\mathrm{~m}^{3}$ & $\mathrm{~m}^{3}$ & $\mathrm{~m}^{3}$ & $\mathrm{~m}^{3}$ & \\
\hline Quantity & $1.4 \times 10^{5}$ & $4.9 \times 10^{7}$ & - & - & $-5.0 \times 10^{6}$ & - & - & -13 \\
\hline
\end{tabular}
Naled ice forms at Finsterwalderbreen during the winter, as

Table 3.Glacial and proglacial solute fluxes during the 1999 sampling season 

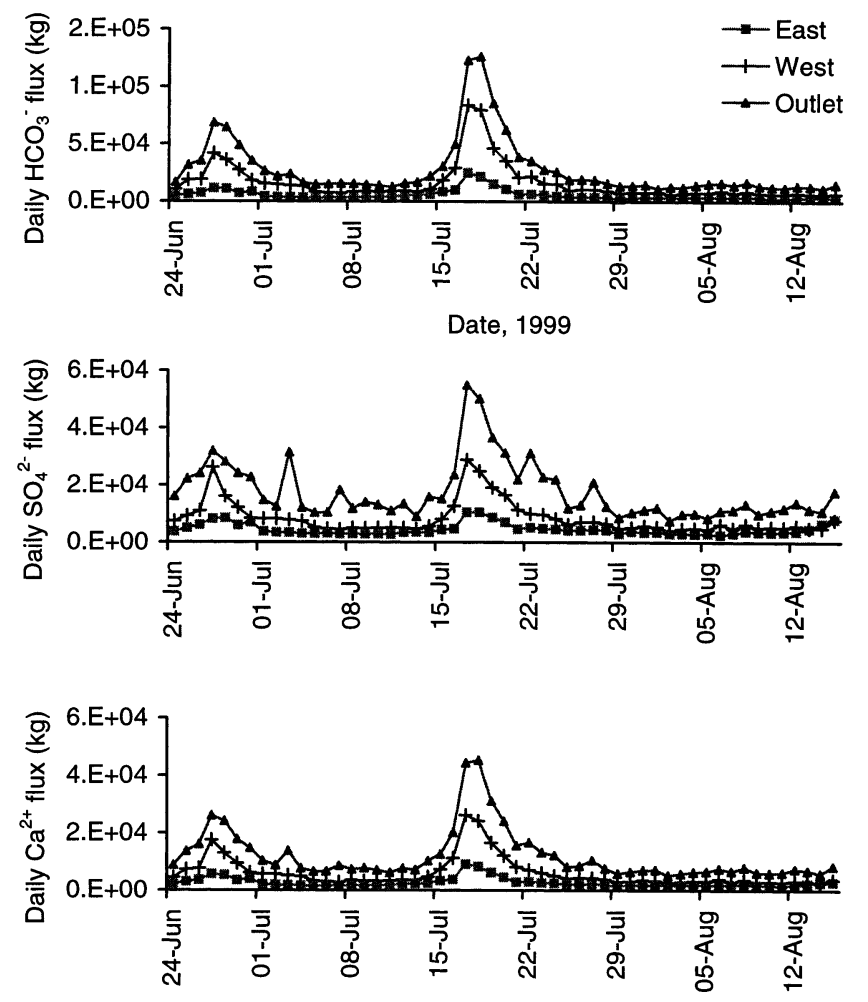

Fig. 4. Temporal variation in the daily fluxes of $\mathrm{HCO}_{3}{ }^{-}, \mathrm{SO}_{4}{ }^{2-}$ and $\mathrm{Ca}^{2+}$ at the East, West and Outlet gauging stations during the 1999 sampling season.

water that is released gradually from subglacial storage accumulates and freezes in the proglacial zone (Wadham and others, 2000). Naled ice is solute-rich (Hodgkins and others, 1997; Wadham and others, 2000). During the summer, the ice melts and solute is gradually leached into the bulk meltwaters as they pass through the proglacial zone. Hence, a component of the proglacial solute flux comprises solute derived from naled ice. Since solute in naled ice is acquired within the glacier, however, this component of the proglacial solute flux should strictly be included in the glacial solute flux. In order to compensate for this, the solute content of naled has been estimated using the mean chemical composition of ice cores collected randomly from different areas of the naled ice fields in spring 1995 and 1996 and the volume of naled formed in these years (Wadham and others, 2000). The latter has been estimated using the depths of cores and the area of the naled, as determined from photographs taken in the field in summer 1995. The potential solute flux due to naled is presented in Table 3. This quantity is negligible compared to $Q_{\mathrm{PG}} C_{\mathrm{PG}}^{\mathrm{i}}$ and $Q_{\mathrm{GL}} C_{\mathrm{GL}}^{\mathrm{i}}$ and can be ignored in calculations. The percentage increase in non-snowpack solute fluxes between the glacier terminus and the Outlet gauging station is also included in Table 3.

\section{Chemical weathering rates}

Chemical weathering rates for the glacier and the proglacial zone are calculated by summing non-snowpack fluxes of $\mathrm{Ca}^{2+}, \mathrm{Mg}^{2+}, \mathrm{Na}^{+}$and $\mathrm{K}^{+}$in meq (Table 3). Summed cation fluxes are then divided by the area over which chemical weathering takes place to give the chemical weathering rate in meq $\Sigma^{+} \mathrm{m}^{-2} \mathrm{a}^{-1}$. Proglacial cation fluxes are divided by the area of the proglacial zone $\left(4.2 \mathrm{~km}^{2}\right)$ to give the proglacial chemical weathering rate. The glacial cation flux is divided
Table 4. Chemical weathering rates $\left(m e q \Sigma^{+} m^{-2} a^{-1}\right)$ at

Finsterwalderbreen during the 1999 sampling season

Catchment chemical weathering rates

Catchment excluding PG zone $\left(63.8 \mathrm{~km}^{2}\right) \quad 540$

Catchment including PG zone $\left(68 \mathrm{~km}^{2}\right) \quad 670$

Glacial chemical weathering rate $\left(44 \mathrm{~km}^{2}\right) \quad 790$

Proglacial chemical weathering rate $\left(4.2 \mathrm{~km}^{2}\right) \quad 2600$

by the area of the glacier, including the two stagnant tributaries $\left(44 \mathrm{~km}^{2}\right)$, to give the glacial chemical weathering rate. This value may be a minimum estimate since although the main body of the glacier is predominantly warm-based (Odegard and others, 1997), the thermal regime of the two tributaries is unknown. It is probable that both these are cold-based and frozen to bedrock. We argue below that even this is not a true glacial chemical weathering rate since a significant proportion of glacial runoff drains via the ice margins rather than the glacier bed. A chemical weathering rate for the entire Finsterwalderbreen catchment has been calculated by dividing the summed glacial and proglacial cation fluxes by the total catchment area $\left(68 \mathrm{~km}^{2}\right)$. The chemical weathering rate for the catchment excluding the proglacial zone $\left(63.8 \mathrm{~km}^{2}\right)$ is also derived. All chemical weathering rates are presented in Table 4 .

\section{DISGUSSION}

\section{The geochemical reactivity of the proglacial zone}

Total non-snowpack solute fluxes increase by $30 \%$ over the $2.5 \mathrm{~km}$ channel reach (Table 3 ), giving rise to an annual proglacial chemical weathering rate of $\sim 2600 \mathrm{meq}^{\Sigma^{+}} \mathrm{m}^{-2}$ (Table 4). This rate is 3.3 times higher than the glacial chemical weathering rate $\left(790 \mathrm{meq} \Sigma^{+} \mathrm{m}^{-2} \mathrm{a}^{-1}\right)$. Inclusion of the proglacial zone in a catchment chemical weathering rate increases solute fluxes by $\sim 20 \%$ for only a $\sim 10 \%$ increase in area. Hence, the proglacial zone at Finsterwalderbreen is highly geochemically reactive. The chemical weathering mechanisms and sources of solute in the proglacial zone are discussed below.

\section{Chemical weathering mechanisms}

High proglacial chemical weathering rates at Finsterwalderbreen are largely due to increases in the fluxes of $\mathrm{HCO}_{3}{ }^{-}$, $* \mathrm{SO}_{4}{ }^{2-}, * \mathrm{Ca}^{2+}$ and $* \mathrm{Mg}^{2+}$ between the glacier terminus and the Outlet gauging station. This can only be explained by the input of solute derived from the chemical weathering of rock material in the proglacial zone. Increases in the fluxes of $* \mathrm{Ca}^{2+}$ and $\mathrm{HCO}_{3}{ }^{-}$indicate the importance of carbonate dissolution in contributing crustal solute to meltwaters. Increases in $* \mathrm{Mg}^{2+}$ are likely to signify the weathering of dolomite and/or other carbonates with a significant $\mathrm{Mg}^{2+}$ content. Smaller increases in $* \mathrm{Na}^{+}$and $* \mathrm{~K}^{+}$and no significant change in Si fluxes suggest that the weathering of silicates, from which these ions largely derive, is less important in the proglacial zone. ${ }^{*} \mathrm{SO}_{4}{ }^{2-}$ fluxes increase the most in the proglacial zone, suggesting that sulphide oxidation is important in supplying protons for these reactions.

The molar flux ratio of ${ }^{*} \mathrm{SO}_{4}{ }^{2-}: \mathrm{HCO}_{3}{ }^{-}$is 0.66 . By contrast, sulphide oxidation coupled to carbonate dissolution generates $\mathrm{SO}_{4}{ }^{2-}$ and $\mathrm{HCO}_{3}{ }^{-}$in a molar ratio of 0.5 
(see Equation (2)). The high molar flux ratio is unlikely to be the consequence of sulphide oxidation linked to silicate dissolution, since the proglacial acquisition of $\mathrm{Si},{ }^{*} \mathrm{Na}^{+}$and $* \mathrm{~K}^{+}$is small (see Table 3 ). No primary gypsum exists in the catchment lithology, but deposits of efflorescent gypsum, which also contain $\mathrm{Mg}^{2+}$, are widespread over the surface of moraines in the proglacial zone. Their dissolution during summer, together with calcite precipitation as a result of the common-ion effect, is likely to produce the observed high molar ratios of $* \mathrm{SO}_{4}{ }^{2-}: \mathrm{HCO}_{3}{ }^{-}$. The over-saturation of ground-waters with respect to calcite (see Table 2) is consistent with this assertion.

\section{Proglacial solute sources}

There are four possible sources of non-snowpack-derived solute within the proglacial zone at Finterwalderbreen, namely, rain, naled ice, SS and the active layer, each of which is discussed below. The potential solute contribution to proglacial solute fluxes from naled ice is minimal (see Table 3). The incidence of rain events in summer 1999 was very low, with only $29 \mathrm{~mm}$ falling during the sampling period. Concentrations of $\mathrm{HCO}_{3}{ }^{-}, \mathrm{SO}_{4}{ }^{2-}, \mathrm{Ca}^{2+}$ and $\mathrm{Mg}^{2+}$ present in rain sampled at Finsterwalderbreen are significantly lower than those observed in the bulk meltwaters (Wadham, 1997). The total proglacial solute flux during the sampling period is estimated to increase by $<1 \%$ as a result of rainfall. This leaves the active layer and bulk meltwater $\mathrm{SS}$ as the only potential solute sources in the proglacial zone.

\section{(a) The active layer as a source of solute to bulk runoff}

The active layer refers to the upper few meters of moraine and fluvial outwash material that lie above the permafrost and thaw seasonally. Soil development in the proglacial zone of Finsterwalderbreen is virtually non-existent, due to rapid retreat of the glacier last century. Two main types of active layer are believed to exist within the proglacial plain. One comprises highly sorted fine-grained fluvial sediments (hereafter fluvial active layer) deposited by the bulk meltwaters during transit through the proglacial plain. These sediments are mainly confined to areas directly bordering the bulk meltwater stream, and in particular the braidedstream section. The other is formed from hummocky moraine and unsorted fluvial sediments (hereafter moraine active layer), and is located at greater distances from the channel and frequently contains buried ice (Hart and Watts, 1997). These are coarse-grained sediments, comprising mainly sand and gravel. This is the dominant active-layer type throughout most of the $4.2 \mathrm{~km}^{2}$ proglacial zone. In both cases, much of the constituent material of the active layer is believed to be subglacial in origin and relatively geochemically reactive because of subglacial comminution of the debris. It is also water-saturated during most of the melt season, due to the input of meltwater from naled ice, supraglacial streams, the bulk meltwater stream and in situ thawing of snow and buried ice.

Active-layer ground-waters drain into the bulk meltwaters via several routes. A number of small streams draining proglacial lakes and the active layer contribute emerged ground-waters directly to the bulk meltwater stream. Ground-waters may also be added to the bulk meltwaters via diffuse flow through the porous active-layer sediments. This latter mechanism of drainage probably becomes more dominant through the melt season as the active layer deepens.
Conversely, bulk meltwaters recharge fluvial active-layer sediments during periods of high bulk meltwater discharge, when the braided stream expands over its flood plain.

Ground-waters in the active layer contain very high concentrations of most solutes relative to the bulk meltwaters (see Table 1; Fig. 3). This suggests that material is highly reactive and that rock/water contact times and rock/ water ratios are high. A chemical composition dominated by $\mathrm{SO}_{4}{ }^{2-}$ indicates that sulphides are abundant in these active-layer sediments and supply protons for carbonate dissolution. The high $\mathrm{PCO}_{2}$ of ground-waters is consistent with this. An additional and related source of $\mathrm{SO}_{4}{ }^{2-}$ is the dissolution of efflorescent gypsum deposits, which also contain $\mathrm{Mg}^{2+}$. These salts re-dissolve during summer, releasing $\mathrm{Ca}^{2+}, \mathrm{Mg}^{2+}$ and $\mathrm{SO}_{4}{ }^{2-}$ into solution. The high $\mathrm{PCO}_{2}$ signature of ground-waters is evidence that waters are actively degassing. This process drives the $\mathrm{pH}$ up and, together with the common-ion effect, increases the $\mathrm{SI}_{\mathrm{C}}$ of ground-waters and promotes calcite precipitation. This explains the depletion of ground-waters in $\mathrm{HCO}_{3}{ }^{-}$relative to $\mathrm{SO}_{4}{ }^{2-}$, giving mean $\mathrm{SO}_{4}{ }^{2-}: \mathrm{HCO}_{3}{ }^{-}$molar ratios of $\sim 4: 1$. The high $\mathrm{PCO}_{2}$ in active-layer ground-waters also prevents the drawdown of atmospheric $\mathrm{CO}_{2}$.

The addition of active-layer ground-water to the bulk meltwaters would impact bulk meltwater stream chemistry and proglacial solute fluxes. Ground-water supply to the bulk meltwaters would be expected to produce the greatest proglacial flux increases in $\mathrm{SO}_{4}{ }^{2-}$ and $\mathrm{Ca}^{2+}$, lesser increases in $\mathrm{HCO}_{3}{ }^{-}$and $\mathrm{Mg}^{2+}$ and minimal increase in $\mathrm{Si}, \mathrm{Na}^{+}$and $\mathrm{K}^{+}$. This is precisely what is revealed in Table 3 , which indicates that $\mathrm{SO}_{4}{ }^{2-}$ and $\mathrm{Ca}^{2+}$ fluxes increase by $30-50 \%, \mathrm{HCO}_{3}{ }^{-}$and $\mathrm{Mg}^{2+}$ fluxes increase by $\sim 30 \%$ and $\mathrm{Si}, \mathrm{Na}^{+}$and $\mathrm{K}^{+}$fluxes increase by $<10 \%$ between the glacier terminus and the Outlet gauging station. Hence, the ground-water hydrochemical record correlates well with proglacial flux increases computed from bulk meltwater records, supporting the active layer as a major source of solute to bulk meltwaters in the proglacial zone. The excess of $* \mathrm{SO}_{4}{ }^{2-}$ over $\mathrm{HCO}_{3}{ }^{-}$in proglacial flux records, however, is much smaller than the * $\mathrm{SO}_{4}{ }^{2-}$ excess in ground-waters. For example, the proglacial flux molar ratio of $* \mathrm{SO}_{4}{ }^{2-}: \mathrm{HCO}_{3}{ }^{-}$is 0.65 (Table 3) compared with molar ratios of $\mathrm{SO}_{4}{ }^{2-}: \mathrm{HCO}_{3}{ }^{-}$concentrations of $\sim 4$ in ground-waters. This indicates that there is some input of $\mathrm{HCO}_{3}{ }^{-}$to bulk meltwaters in the proglacial zone in addition to that supplied by the active layer.

\section{(b) In-channel chemical weathering of $S S$}

Laboratory dissolution experiments suggest that SS may be a significant source of crustal solute to bulk meltwaters in the proglacial zone. They demonstrate bulk meltwater SS to be relatively reactive, releasing concentrations of 300 $400 \mu \mathrm{eq} \mathrm{L}{ }^{-1}$ of $\mathrm{Ca}^{2+}$ and $\mathrm{HCO}_{3}{ }^{-}$within 30 min when SSC is $2-3 \mathrm{~g} \mathrm{~L}^{-1}$ (Fig. 5). These $\mathrm{SSC}$ values are similar to those reported in the West bulk meltwaters in previous years (Hodson and others, 1997). Clearly, rock/water contact times and SSC are significant in determining the amount of solute acquired from SS. Variations in these factors may therefore be responsible for fluctuations in proglacial solute fluxes. However, it is difficult to transfer the results of the dissolution experiments directly to the bulk runoff in the proglacial channel. First, the wetting history of the SS is not known, and this affects the amount of $\mathrm{SO}_{4}{ }^{2-}$ that is released. Second, the bulk meltwater already contains solute, which diminishes the rate of solute acquisition. The experiments 
a

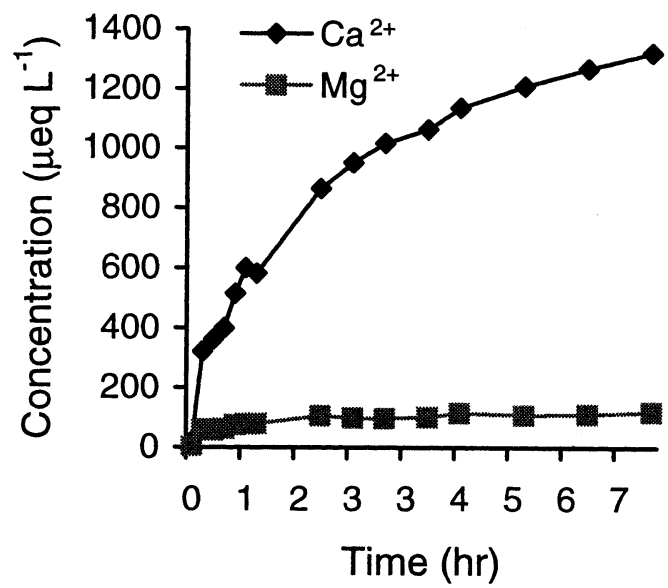

b

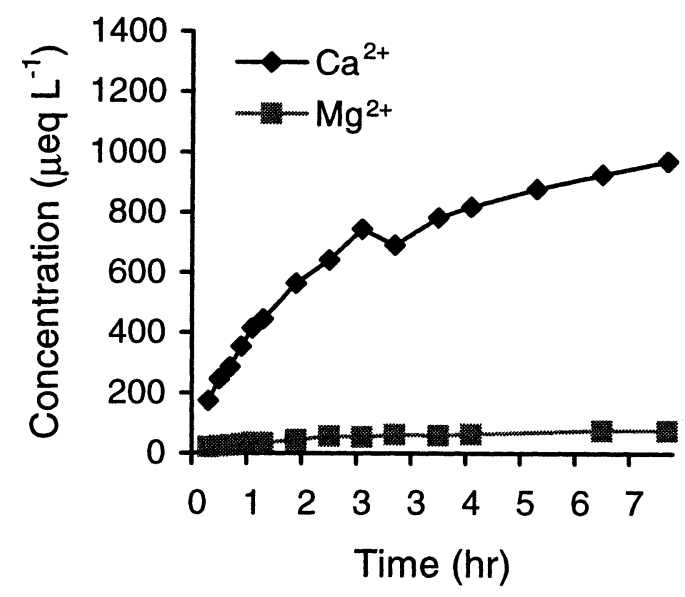

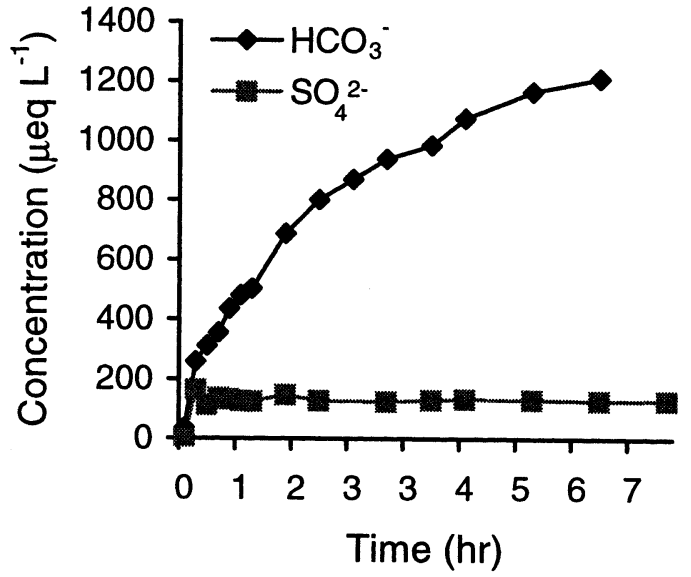

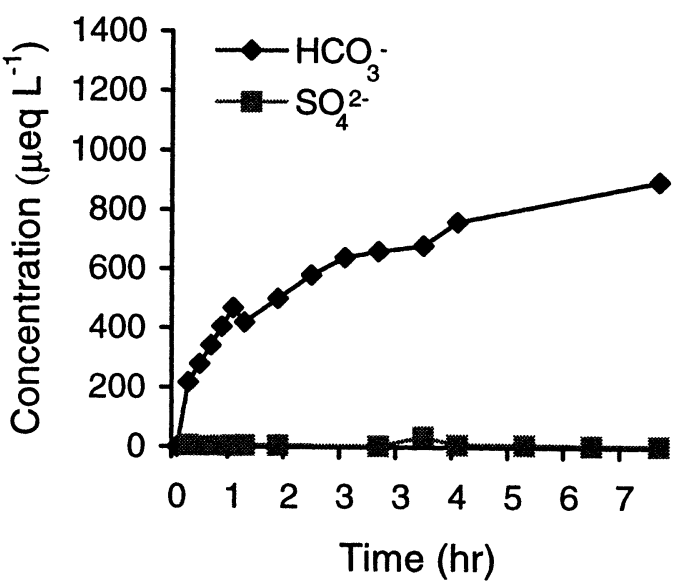

Fig. 5. Temporal variation in the concentrations of $\mathrm{HCO}_{3}{ }^{-}, \mathrm{SO}_{4}{ }^{2-}, \mathrm{Mg}^{2+}$ and ${ }^{*} \mathrm{Ca}^{2+}$ acquired in dissolution experiments where SSC was (a) $3 g L^{-1}$ and (b) $2 g L^{-1}$.

do show that the SS is geochemically reactive and supplies $\mathrm{Ca}^{2+}$ and $\mathrm{HCO}_{3}{ }^{-}$to solution, but the amount of $\mathrm{SO}_{4}{ }^{2-}$ is likely to be limited unless significant concentrations of new sediment are eroded.

The source of protons for proglacial SS dissolution is unlikely to be atmospheric $\mathrm{CO}_{2}$. Figure 3 shows that the $\mathrm{PCO}_{2}$ of bulk meltwaters sampled at the East, West and Outlet gauging stations was above the atmospheric $\mathrm{PCO}_{2}$ during most of the sampling season. Hence, drawdown of atmospheric $\mathrm{CO}_{2}$ could only occur during restricted time periods. Outside of these periods, SS dissolution must be fuelled by $\mathrm{CO}_{2}$ already in solution. High $\mathrm{PCO}_{2}$ groundwaters that evolve by coupled sulphide oxidation/carbonate dissolution (Equation (2)) in the active layer are added to the bulk meltwaters, where they may promote some dissolution of SS. Further, proglacial solute may be acquired as the braided bulk meltwater stream expands over its flood plain during high discharges. Here, carbonate dissolution may be fuelled by in situ sulphide oxidation.

\section{Proglacial chemical weathering}

The above discussion indicates that proglacial chemical weathering rates at Finsterwalderbreen are high and result primarily from the dissolution of reactive material in the proglacial active layer. Ground-water hydrochemistry data demonstrate that the immediate proglacial zone may actually serve as a source of $\mathrm{CO}_{2}$ to the atmosphere.

Proglacial solute fluxes and chemical weathering rates presented in this paper may be upper estimates of chemical weathering in the proglacial zones of glacierized catchments more generally, for four main reasons. First, reactive minerals such as sulphides and carbonates are a major component of catchment lithology at Finsterwalderbreen, thereby increasing the reactivity of both fluvial outwash and morainic material in the proglacial zone compared to glaciers on more crystalline bedrocks. Second, a predominantly warm basal thermal regime serves to enhance rates of subglacial erosion and comminution, further increasing the reactivity of subglacial debris and the rate of sediment delivery to the proglacial zone, either by subglacial meltwaters or by advection in the basal ice. Third, most of the proglacial zone has become exposed since 1920, with a retreat rate of $>40 \mathrm{ma}^{-1}$ since 1970 (Nuttall, 2000). Proglacial active-layer debris is therefore relatively young. In older proglacial areas, exhaustion of sulphides may increase the degree to which $\mathrm{CO}_{2}$ is drawn down from the atmosphere during chemical weathering (Anderson and others, 2000). Finally, a complex network of lakes provides a continuous source of meltwater to active-layer deposits through the melt season, and an extensive, dynamic braided-stream network in the proglacial zone enables bulk meltwaters to interact directly with moraine and fluvial deposits of the active layer. This contrasts with work conducted by Fairchild and others, (1999) at Glacier de Tsanfleuron, Switzerland, where SS was the only significant source of solute to bulk meltwaters, in part due to the limited interaction of spring snowmelt with proglacial moraines. 


\section{CONGLUSIONS}

Bulk meltwater hydrochemical data show that solute fluxes increase on average by $30 \%$ in the proglacial zone. The greatest crustal flux increases of $30-50 \%$ are displayed by $* \mathrm{SO}_{4}{ }^{2-}$ and $* \mathrm{Ca}^{2+}, \mathrm{HCO}_{3}{ }^{-}$and $* \mathrm{Mg}^{2+}$, while fluxes of $* \mathrm{Na}^{+}, * \mathrm{~K}^{+}$increase by $\sim 10 \%$. There is no significant change in Si fluxes. A major source of non-snowpack-derived solute for bulk meltwaters in the proglacial zone is the active layer. Active-layer ground-waters have a composition of the type $\mathrm{SO}_{4}{ }^{2-}-\mathrm{Ca}^{2+}-\mathrm{Mg}^{2+}-\mathrm{HCO}_{3}{ }^{-}$and evolve by coupled sulphide oxidation/ carbonate dissolution, gypsum precipitation and re-dissolution. The common-ion effect and degassing of $\mathrm{CO}_{2}$ result in the saturation of ground-waters with respect to calcite. A significant proportion of $\mathrm{HCO}_{3}{ }^{-}$and some $\mathrm{Ca}^{2+}$ is removed from solution by calcite precipitation, producing ground-waters that are depleted in $\mathrm{HCO}_{3}{ }^{-}$relative to $\mathrm{SO}_{4}{ }^{2-}$. The high $\mathrm{PCO}_{2}$ signature of active-layer ground-waters suggests solute acquisition in the active layer does not draw down any $\mathrm{CO}_{2}$ from the atmosphere. Solute flux enhancement occurs when concentrated active-layer ground-waters drain into the bulk meltwater stream by direct and diffuse flow paths. A significant component of the proglacial $* \mathrm{Ca}^{2+}$ and $\mathrm{HCO}_{3}{ }^{-}$flux is acquired by in-channel chemical weathering of bulk meltwater SS and the dissolution of fluvially derived active-layer sediments. Carbonate in the SS is dissolved by protons generated by carbonation in the bulk meltwaters and by sulphide oxidation in the active layer. Chemical weathering rates are $\sim 3.3$ times greater than those reported from the glacierized part of the catchment, confirming the active layer as a significant solute source, and the proglacial zone as highly geochemically reactive. These findings are, in part, linked to the glacier's polythermal regime, a bedrock lithology with a significant carbonate and sulphide content and relatively rapid retreat rates of the terminus last century.

\section{ACKNOWLEDGEMENTS}

This work was funded by the U.K. Natural Environment Research Council ARCICE thematic programme and tied studentship GT24/98/ARCI/8 (to R.J.C.). We are grateful to M. J. Sharp and S. P. Anderson for their comments on an earlier draft, which resulted in significant improvements to the text. We would like to thank the Norsk Polarinstitutt for logistical support, and D. Jenkins for assistance in the field. Thanks are also due toJ. Mills for assistance with laboratory analysis, and S. Godden for assistance with preparation of the figures.

\section{REFERENGES}

Anderson, S. P., J. I. Drever and N. F. Humphrey. 1997. Chemical weathering in glacial environments. Geology, 25(5), 399-402.

Anderson, S. P., J. I. Drever, C. D. Frost and P. Holden. 2000. Chemical weathering in the foreland of a retreating glacier. Geochim. Cosmochim. Acta, 64(7), 1173-1189.

Dallmann, W. K. and 7 others. 1990. Van Keulenfjorden. Oslo, Norsk Polarinstitutt. (Geological map, Svalbard Sheet BllG.)

Fairchild, I. J. and 6 others. 1999. Solute generation and transfer from a chemically reactive alpine glacial-proglacial system. Earth Surf. Processes Landforms, 24(13), 1189-1211.

Gibbs, M.T. and L. R. Kump. 1994. Global chemical erosion during the Last Glacial Maximum and the present: sensitivity to changes in lithology and hydrology. Paleoceanography, 9(4), 529-543.

Hart, J. K. and R. Watts. 1997. A comparison of the styles of deformation associated with two recent push moraines, south Van Keulenfjorden, Svalbard. Earth Surf. Processes Landforms, 22(12), 1089-1107.

Hodgkins, R., M. Tranter and J. A. Dowdeswell. 1997. Solute provenance, transport and denudation in a High-Arctic glacierised catchment. Hydrol. Processes, 11 (4), 1813-1832.

Hodson, A. J., M. Tranter, J. A. Dowdeswell, A. M. Gurnell and J. O. Hagen. 1997. Glacier thermal regime and suspended-sediment yield: a comparison of two high-Arctic glaciers. Ann. Glaciol., 24, 32-37.

Holland, H. D. 1978. The chemistry of the atmosphere and oceans. New York, WileyInterscience.

Liestøl, O. 1969. Glacier surges in West Spitsbergen. Can. F. Earth Sci., 6(4), Part 2, 895-897.

Metcalf, R.C. 1986. The cationic denudation rate of an Alpine glacial catchment. Z. Gletscherkd. Glazialgeol., 22(1), 19-32.

Nuttall, A.-M. 2000. The quiescent phase of Finsterwalderbreen, a surge type glacier in Svalbard. (Ph.D., University of Bristol.)

Nuttall, A.-M., J. O. Hagen and J. Dowdeswell. 1997. Quiescent-phase changes in velocity and geometry of Finsterwalderbreen, a surge-type glacier in Svalbard. Ann. Glaciol., 24, 249-254.

Ødegård, R. S., J. O. Hagen and S.-E. Hamran. 1997. Comparison of radioecho sounding (30-1000 MHz) and high-resolution borehole-temperature measurements at Finsterwalderbreen, southern Spitsbergen, Svalbard. Ann. Glaciol., 24, 262-267.

Parkhurst, D. L. and C. A. J. Appelo, 1999. User's guide to PHREEQC (Version 2) - a computer program for speciation, batch-reaction, onedimensional transport, and inverse geochemical calculations. U.S. Geol. Surv. Water-Resour. Invest. Rep. 99-4259.

Plummer, L. N. and E. Busenberg. 1982. The solubilities of calcite, aragonite and vaterite in $\mathrm{CO}_{2}-\mathrm{H}_{2} \mathrm{O}$ solutions between 0 and $90^{\circ} \mathrm{C}$, and an evaluation of the aqueous model for the system $\mathrm{CaCO}_{3}-\mathrm{CO}_{2}-\mathrm{H}_{2} \mathrm{O}$. Geochim. Cosmochim. Acta, 46, 1011-1040.

Reynolds, R. C. and N. M. Johnson. 1972. Chemical weathering in the temperate glacial environment of the northern Cascade Mountains. Geochim. Cosmochim. Acta, 36(5), 537-554.

Sharp, M., M. Tranter, G. H. Brown and M. Skidmore. 1995. Rates of chemical denudation and $\mathrm{CO}_{2}$ draw-down in a glacier-covered Alpine catchment. Geology, 23(1), 61-64.

Tranter, M. and 9 others. 1997. Variability in the chemical composition of in situ subglacial meltwaters. Hydrol. Processes, 11, 59-78.

Tranter, M., M. J. Sharp, H. R. Lamb, G. H. Brown, B. P. Hubbard and I. C. Willis. In press. Geochemical weathering at the bed of Haut Glacier d'Arolla, Switzerland - a new model. Hydrol. Processes.

Wadham, J. L. 1997. The hydrochemistry of a High Arctic polythermalbased glacier, Finsterwalderbreen, Svalbard. (Ph.D. thesis, University of Bristol.)

Wadham, J. L., A. J. Hodson, M. Tranter and J. A. Dowdeswell. 1997. The rate of chemical weathering beneath a quiescent, surge-type, polythermalbased glacier, southern Spitsbergen, Svalbard. Ann. Glaciol., 24, 27-31.

Wadham, J. L., A. J. Hodson, M. Tranter and J. A. Dowdeswell. 1998. The hydrochemistry of meltwaters draining a polythermal-based high Arctic glacier, southern Svalbard. I. The ablation season. Hydrol. Processes, 12, $1825-1849$.

Wadham, J. L., M. Tranter and J. A. Dowdeswell. 2000. The hydrochemistry of meltwaters draining a polythermal-based high Arctic glacier, southern Svalbard. II. Winter and early spring. Hydrol. Processes, 14, 1767-1786. 